\title{
Integrasi Budidaya Ikan Patin (Pangasius hypophthalmus) dan Tanaman Air Pada Pemeliharaan Sistem Akuaponik
}

\author{
${ }^{* 1}$ Muarofah Ghofur, ${ }^{1}$ M.Sugihartono dan ${ }^{2}$ Nur Rizki \\ ${ }^{1}$ Program Studi Budidaya Perairan Fakultas Pertanian Universitas Batanghari \\ ${ }^{2}$ Alumni Program Studi Budidaya Perairan Fakultas Pertanian Universitas Batanghari \\ Jl. Slamet Riyadi, Broni, Jambi, 36122. Telp. +6074160103 \\ ${ }^{* 1}$ e-mail Korespondensi : muarofah_ghofur@yahoo.com
}

\begin{abstract}
The purpose of this study is to find out whether the integration of catfish cultivation (P. hypophthalmus) and aquatic plants in the maintenance of aquaponic systems in order to produce high fish survival. The research was conducted using a Complete RandomIzed Design (RAL) environmental design with 4 (four) treatments and 3 (three) replays, each of these treatments is :P A behavior: 10 plant stems / holes and 2 fish / liter, Treatment B : 10 plant stems / holes and 3 fish / liters, Treatment $C: 10$ plant stems / holes and 4 fish / liter, Treatment D : 10 plant stems / holes and 5 fish / liter. The observed parameters are survival, growth and measurement of water quality. The results showed that the survival rate of catfish was $85.18 \%, 2.38 \mathrm{~cm}$ for length gain and weight gain of $2.80 \mathrm{~g}$.
\end{abstract}

Keywords : Aquaponics, Catfish, Aquatic Plants

\begin{abstract}
Abstrak. Tujuan dari penelitian ini adalah untuk mengetahui adakah hasil integrasi budidaya ikan patin (P. hypophthalmus) dan tanaman air pada pemeliharaan sistem akuaponik agar dapat menghasilkan kelangsungan hidup ikan yang tinggi. Penelitian dilakukan menggunakan rancangan lingkungan Rancangan Acak Lengkap (RAL) dengan 4 (empat) perlakuan dan 3 (tiga) ulangan, masing - masing perlakuan tersebut adalah :Perlakuan A : 10 batang tanaman/lubang dan 2 ekor ikan/liter, Perlakuan B : 10 batang tanaman/lubang dan 3 ekor ikan/liter, Perlakuan C : 10 batang tanaman/lubang dan 4 ekor ikan/liter, Perlakuan D : 10 batang tanaman/lubang dan 5 ekor ikan/liter. Parameter yang diamati adalah kelangsungan hidup, pertumbuhan dan pengukuran kualitas air. Hasil penelitian menunjukkan bahwa tingkat kelangsungan hidup ikan patin sebesar $85.18 \%, 2.38 \mathrm{~cm}$ untuk pertambahan panjang dan pertambahan bobotnya sebesar $2.80 \mathrm{~g}$.
\end{abstract}

Kata kunci : Akuaponik, Ikan Patin, Tanaman air

\section{PENDAHULUAN}

Inovasi teknologi diperlukan untuk mengantisipasi penurunan produksi akuakultur akibat penyusutan lahan budidaya dan penurunan kualitas perairan. Inovasi teknologi tersebut diharapkan mampu mengurangi limbah dan meningkatkan produktifitas persatuan luas lahan budidaya. Salah satu inovasi teknologi yang diterapkan yaitu budidaya ikan yang terintegrasi dengan tanaman melalui sistem akuaponik. Teknologi akuaponik terbukti mampu berhasil memproduksi ikan secara optimal pada lahan sempit dan sumber air terbatas, termasuk di daerah perkotaan. Teknologi ini pada prinsipnya disamping menghemat penggunaan lahan dan air juga meningkatkan efisiensi usaha melalui pemanfaatan hara dari sisa pakan dan metabolisme ikan untuk tanaman air serta merupakan salah satu sistem budidaya ikan yang ramah lingkungan (Chou, 1994). Akuaponik (aquaphonic) merupakan salah satu teknologi budidaya yang mengkombinasikan pemeliharaan ikan dengan tanaman. Sistem ini dapat menghemat penggunaan air dalam budidaya ikan sampai $97 \%$ (Effendi, 2000).

Interaksi antara ikan dan tanaman pada sistem ini menciptakan lingkungan tumbuh yang lebih produktif dari metode konvensional. Budidaya menggunakan sistem akuaponik lebih ramah lingkungan karena tidak menghasilkan limbah sehingga tidak membahayakan lingkungan (Zero Enviromental Impact) dibandingkan dengan sitem budidaya lainnya. Menurut Chou (1994), sistem akuaponik dapat menghasilkan ikan dan tanaman organik yang berkualitas tinggi, yaitu produk yang terbebas dari zat kimia yang berasal dari penggunaan pupuk buatan, pestisida maupun herbisida. Selain menghemat penggunaan lahan dan air, sistem akuaponik juga meningkatkan efisiensi usaha melalui pemanfaatan hara dari sisa pakan dan metabolisme ikan. Sisa pakan dan hasil metabolisme ikan (feses dan urin) akan menghasilkan limbah berupa ammonia. Ammonia yang terlalu banyak dalam wadah budidaya akan menjadi racun bagi ikan. Menurut Forteath (1993), pada sistem akuaponik, bakteri yang terdapat dalam media tumbuh tanaman dan wadah pemeliharaan ikan akan mengubah ammonia menjadi nitrit dan nitrat. Pada tanaman, nitrat berfungsi sebagai nutrisi. Air yang kaya nutrisi dari wadah pemeliharaan disalurkan kepada tanaman, kemudian dimanfaatkan sebagai hara. Oleh karena itu penggunaan teknologi budidaya akuaponik diharapkan mampu memperbaiki kualitas air pada budidaya ikan dengan kepadatan tinggi sehingga dapat mengurangi tingkat kematian ikan. Untuk itu kita perlu mengetahui bagaimana hasil integrasi budidaya ikan patin (P.hypophthalmus) dan tanaman air pada pemeliharaan sistem akuaponik untuk meningkatkan kelangsungan hidup benih ikan patin dan juga degradasi amoniak pada sistem akuaponik dengan integrasi budidaya ikan patin (P.hypophthalmus) dan tanaman air untuk meningkatkan kelangsungan hidup ikan. 
Tujuan dari penelitian ini adalah untuk mengetahui adakah hasil integrasi budidaya ikan patin ( $P$. hypophthalmus) dan tanaman air pada pemeliharaan sistem akuaponik agar dapat menghasilkan kelangsungan hidup ikan yang tinggi. Kelangsungan hidup ikan sangat terkait dengan peranan tanaman air yang berfungsi sebagai fitoremediasi perairan, demikian juga sebalilknya bahan organic yang dihasilkan oleh ikan (sisa pakan, urin dan feses) diperlukan oleh tanaman untuk tumbuh, sehingga diharapkan akumulasi amoniak dalam perairan akan dapat dieliminasi, terutama pada media pemeliharaan tanpa pergantian air (system akuaponik).

\section{METODOLOGI PENELITIAN}

Penelitian ini rencananya akan dilaksanakan pada bulan Maret sampai bulan Juli tahun 2020 di Balai Benih Ikan Daerah Telanaipura Provinsi Jambi dan Laboratorium Dasar Universitas Batanghari Jambi.

Adapun alat yang digunakan dalam pelaksanaan penelitian ini antara lain : akuarium, pompa air, blower, serok halus, pipa paralon, keran air, literan air, baskom, selang sifon, alat pengukur kualitas air, timbangan digital, alat tulis, kamera digital, mistar, genset, akuaponik set.

Bahan yang akan digunakan adalah benih ikan patin sebanyak 2.100 ekor dari induk yang sama yaitu hasil pemijahan secara alami di Balai Benih Ikan Daerah Telanaipura Provinsi Jambi dan benih tanaman air sebanyak 240 batang.

Penelitian yang dilakukan menggunakan rancangan lingkungan Rancangan Acak Lengkap (RAL) dengan 4 (empat) perlakuan dan 3 (tiga) ulangan, masing - masing perlakuan tersebut adalah :Perlakuan A : 10 batang tanaman/lubang dan 2 ekor ikan/liter, Perlakuan B : 10 batang tanaman/lubang dan 3 ekor ikan/liter, Perlakuan C : 10 batang tanaman/lubang dan 4 ekor ikan/liter, Perlakuan D : 10 batang tanaman/lubang dan 5 ekor ikan/liter.

Pelaksanaan penelitian akan menggunakan sistem akuaponik yaitu suatu sistem budidaya yang memanfaatkan secara terus menerus air dari pemeliharaan ikan ke tanaman dan sebaliknya dari tanaman ke kolam ikan. Inti dasar dari sistem teknologi ini adalah penyediaan air yang optimum untuk masing-masing komoditas dengan memanfaatkan sistem resirkulasi.

Dengan memanfaatkan sistem akuaponik, di harapkan dapat mereduksi konsentrasi TOC dalam kolam budidaya melalui tanaman yang digunakan. Fokus dalam akuakultur adalah memaksimalkan pertumbuhan ikan di dalam kolam pemeliharaan. Ikan biasanya ditebar pada kolam dengan kepadatan yang tinggi. Tingkat penebaran ikan yang tinggi menyebabkan kebutuhan akan oksigen 10 menjadi meningkat dan terjadi penurunan kualitas air budidaya akibat feses dan pakan yang tidak termakan. Akuaponik menyatukan simbiosis antara tanaman dan ikan, dimana tanaman memanfaatkan kotoran ikan yang berisi hampir semua nutrisi yang dibutuhkan untuk pertumbuhan dan proses fotosintesis, sehingga mampu memberikan suplai oksigen dan menjaga kualitas air untuk pertumbuhan ikan yang dibudidayakan (Ahmad dkk., 2007).

Tanaman air yang telah siap tanam dimasukkan ke dalam lubang pada system akuaponik sesuai dengan kepadatan pada perlakuan. Kemudian benih ikan patin ( $P$. hypophthalmus) berukuran 1 inchi, dimasukkan ke dalam akuarium sistem akuaponik dengan jumlah volume air pada masing-masing akuarium sebanyak 50 liter, kepadatan ikan sesuai perlakuan. Ikan uji diberikan pakan pellet 3 (tiga) kali sehari dengan menggunakan metode adlibitum.

Pada masa pemeliharaan dengan sistem akuaponik ini tidak dilakukan penyiphonan maupun pergantian air karena justru feses ikan diperlukan untuk sumber hara tanaman yang dipelihara. Pada akhir penelitian akan dilakukan perhitungan kelangsungan hidup ikan uji. Setelah penelitian selesai, dilakukan penghitungan kelangsungan hidup benih, pertumbuhan dan pengukuran kualitas air. Setelah itu data yang telah diperoleh kemudian ditabulasi dan dianalisis sesuai dengan tujuan penelitian. Data parameter derajat kelangsungan hidup, dianalisis menggunakan analisis ragam (ANOVA) pada selang kepercayaan 95\%. Analisis ini digunakan untuk menentukan apakah perlakuan berpengaruh nyata terhadap derajat kelangsungan hidup. Apabila berpengaruh nyata, untuk melihat perbedaan antar perlakuan akan diuji lanjut menggunakan uji Tukey. Analisis deskripsi kuantitatif berupa tabel digunakan untuk menjelaskan kelayakan media pemeliharaan bagi kehidupan benih ikan lele selama penelitian. Analisis data menggunakan perangkat lunak Ms.Excel 2007 dan SPSS 16.0.

\section{HASIL DAN PEMBAHASAN}

Berdasarkan hasil penelitian tingkat kepadatan benih ikan patin siam (Pangasianodon hypopthalmus $\mathrm{F}$ ) pada pemeliharaan dengan sistem akuaponik selama 30 hari, didapatkan perbedaan jumlah tingkat kelangsungan hidup (SR), pertambahan panjang dan bobot benih ikan patin siam pada setiap perlakuan. Hasil rata - rata dari masing masing parameter yang diuji dalam penelitian tersebut dapat dilihat pada Tabel 3 berikut ini. 
Tabel 1. Parameter produksi ikan patin siam dengan tingkat kepadatan benih yang berbeda dengan sistem akuaponik

\begin{tabular}{clcccc}
\hline \multirow{2}{*}{ NO. } & \multicolumn{1}{c}{ Parameter } & \multicolumn{4}{c}{ Perlakuan } \\
\cline { 3 - 5 } & & A & B & C & D \\
\hline 1 & Kelangsungan Hidup (\%) & $85,18^{\mathrm{b}}$ & $49,13^{\mathrm{a}}$ & $52,59^{\mathrm{a}}$ & $43,84^{\mathrm{a}}$ \\
2 & Pertambahan Panjang Mutlak (cm) & $2,11^{\mathrm{a}}$ & $2,06^{\mathrm{a}}$ & $2,38^{\mathrm{b}}$ & $2,32^{\mathrm{ab}}$ \\
3 & Pertambahan Berat Mutlak (g) & $2,37^{\mathrm{a}}$ & $2,80^{\mathrm{a}}$ & $2,63^{\mathrm{a}}$ & $2,37^{\mathrm{a}}$ \\
\hline
\end{tabular}

Keterangan : Angka - angka yang diikuti oleh huruf yang berbeda menunjukkan perlakuan berbeda nyata pada Uji Tuckey taraf $5 \%$.

\section{Kelangsungan Hidup Benih Ikan Patin Siam (P. hypopthalmus, F)}

Berdasarkan data pada tabel 3 di atas terlihat bahwa tingkat kepadatan benih yang berbeda pada pemeliharaan sistem akuaponik sangat memberikan pengaruh yang nyata terhadap tingkat kelangsungan hidup ikan patin siam $(P$. hypopthalmus, F). Jumlah rata-rata tingkat kelangsungan hidup dari masing-masing perlakuan disajikan dalam bentuk diagram batang pada gambar 3.

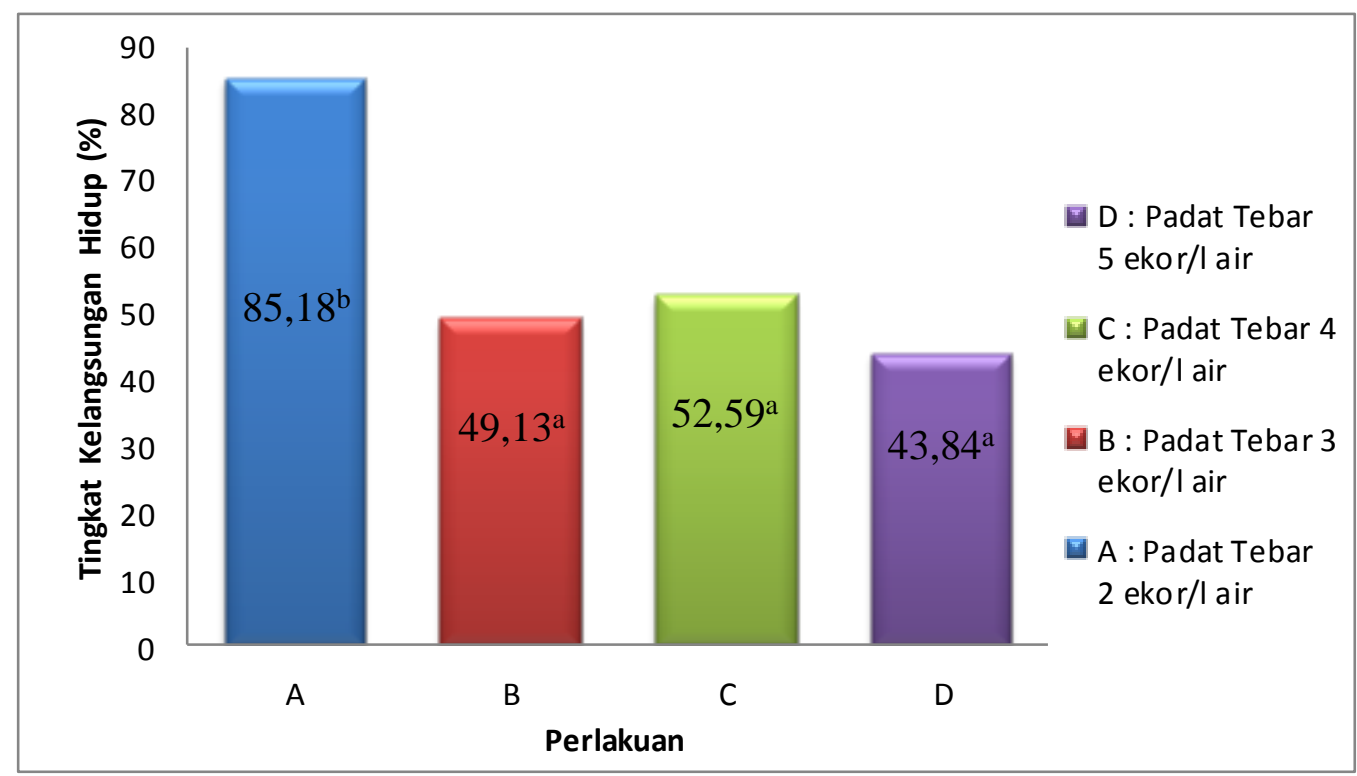

Gambar 1. Rata-rata tingkat kelangsungan hidup ikan patin siam

Pada gambar 1 menunjukkan bahwa pada perlakuan A (padat tebar 2 ekor/l air), memberikan rata - rata tingkat kelangsungan hidup benih ikan patin siam ( $P$. hypopthalmus, F) paling tinggi dengan persentase 85,18\%, kemudian diikuti oleh perlakuan $\mathrm{C}$ (padat tebar 4 ekor/l air) dengan persentase tingkat kelangsungan hidup sebesar $52,59 \%$, dilanjutkan dengan perlakuan B padat tebar 3 ekor/l air) dengan persentase tingkat kelangsungan hidup sebesar 49,13\% dan perlakuan D (padat tebar 5 ekor/l air) dengan persentase tingkat kelangsungan hidup sebesar 43,84\%. Berdasarkan analisis sidik ragam pemeliharaan benih ikan patin siam ( $P$. hypopthalmus, F) dengan tingkat padat tebar yang berbeda dalam pemeliharaan sistem akuaponik berpengaruh nyata terhadap kelangsungan hidup benih ikan patin siam ( $P$. hypopthalmus, $\mathrm{F})(\mathrm{P}<0,05)$. (Tabel 3).

Mortalitas adalah kematian yang terjadi pada suatu populasi organisme yang dapat menyebabkan turunnya jumlah populasi (Effendie, 1997). Jika diperoleh nilai SR yang tinggi maka kegiatan budidaya tersebut dapat dikatakan berhasil dan begitu juga sebaliknya. Kelangsungan hidup dipengaruhi oleh dua faktor yaitu faktor dari dalam ikan itu sendiri dan faktor dari lingkungan luar. Faktor dari dalam diantaranya umur ikan, ukuran dan kemampuan ikan beradaptasi dengan lingkungan, sedangkan faktor dari luar meliputi kondisi fisik-kimia dan media biologi, ketersediaan makanan, kompetisi antar ikan dalam mendapatkan makanan apabila jumlah makanan dalam media pemeliharaan kurang mencukupi, serta proses penanganan ikan yang kurang baik (Royce, 1972).

Pada perhitungan ANOVA tingkat Survival Rate menghasilkan perbedaan yang nyata pada setiap perlakuan. Hal ini disebabkan Pada kondisi media pemeliharaan dengan padat tebar yang tinggi, kualitas air menjadi semakin cepat buruk. Kandungan ammonia hasil metabolisme yang meningkat dapat menyebabkan gangguan yang bersifat fisiologis dan memicu stress pada ikan (Boyd, 1990). Stres pada ikan mengakibatkan turunnya daya tahan tubuh dan menurunnya nafsu makan sampai mengakibatkan terjadinya kematian (Effendi, 2003). 
Pada perlakuan A (2 ekor/l air) memiliki tingkat Survival Rate yang paling tinggi dan pada perlakuan D (5 ekor/l air) memiliki tingkat Survival Rate terendah yang disebabkan oleh kualitas air yang terbentuk karena perbedaan padat tebar pada volume akuarium pemeliharaan yang seragam. Aktivitas budidaya ikan tidak terlepas dari limbah yang dihasilkan, terutama dari sisa pakan, feses, dan hasil aktivitas metabolisme ikan. Penyebab rendahnya SR pada perlakuan B, C dan D diduga disebabkan oleh kualitas air yang semakin hari semakin menurun, sebab pada penelitian ini tidak dilakukan pergantian air selama masa pemeliharaan. Penurunan kualitas air media pemeliharaan ikan dapat diakibatkan oleh sisa pakan dan kotoran ikan yang mengendap di dasar perairan sehingga mengakibatkan naiknya kandungan amonia di dalam air.

Pada sistem budidaya tanpa pergantian air (zero water exchange), konsentrasi limbah budidaya seperti amonia (NH3), nitrit (NO2), dan karbon dioksida $\mathrm{CO} 2$ akan meningkat sangat cepat dan bersifat toksik bagi organisme budidaya (Surawidjaja, 2006 dalam Wijaya dkk, 2014). Nugroho dkk (2012) menambahkan, kepadatan atau kerapatan tebar benih ikan yang dibudidayakan harus disesuaikan dengan standar atau tingkatan budidaya. Dari hasil penelitian menunjukkan bahwa pada sistem akuaponik, faktor kepadatan tebar tidak berpengaruh terhadap tingkat kelangsungan hidup benih ikan patin siam, fungsi sistem akuaponik hanya mampu menunjang kegiatan pendederan sebagaimana standar kepadatan tebar sistem budidaya normal. Peningkatan kepadatan akan menyebabkan daya dukung kehidupan ikan per individu menurun. Kepadatan yang terlalu tinggi (overstocking) akan meningkatkan kompetisi pakan, ikan mudah stress dan akhirnya akan menurunkan konversi pakan dan kecepatan pertumbuhan (Tacon,1987).

\section{Pertambahan Panjang Benih Ikan Patin Siam (P. hypopthalmus, F)}

Berdasarkan data pada tabel 3 di atas terlihat bahwa tingkat kepadatan benih yang berbeda pada pemeliharaan sistem akuaponik memberikan pengaruh terhadap pertumbuhan benih ikan patin siam ( $P$. hypopthalmus, F) baik panjang tubuh dan bobot tubuh ikan patin siam.

Jumlah rata-rata pertambahan panjang benih ikan patin siam selama 30 hari dari masing-masing perlakuan disajikan dalam bentuk grafik pada gambar 4.

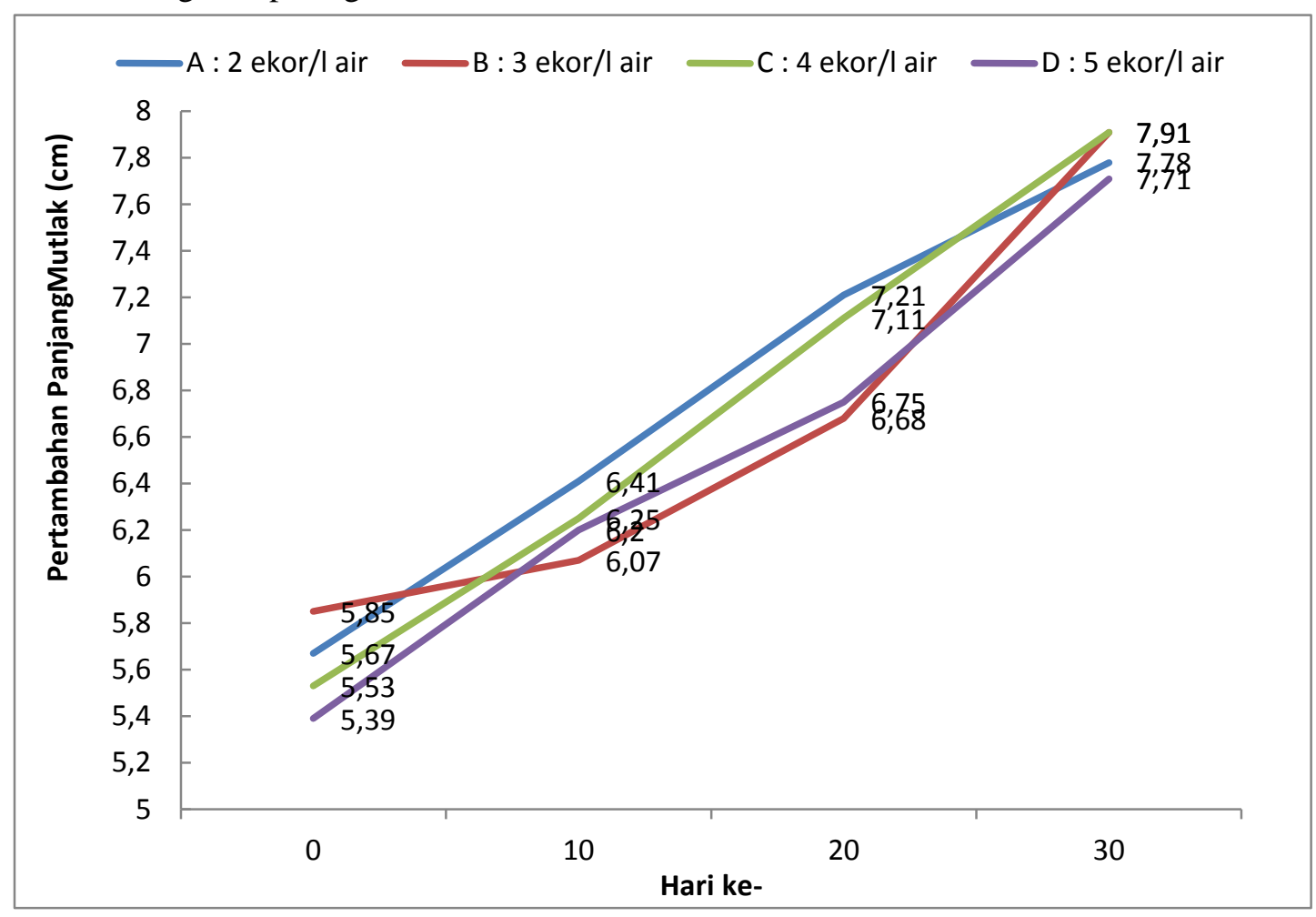

Gambar 2. Grafik pertambahan panjang benih ikan patin siam

Grafik pada gambar 2 menunjukkan bahwa pada perlakuan B dan C (padat tebar 2 dan 3 ekor/l air) memberikan rata - rata pertambahan panjang benih ikan patin siam ( $P$. hypopthalmus, $\mathrm{F}$ ) yang paling tinggi yaitu $7,91 \mathrm{~cm}$, kemudian diikuti perlakuan perlakuan A (padat tebar 2 ekor/l air) dengan rata - rata pertambahan panjang sebesar 7,78 cm, dan pertambahan panjang terendah ada pada perlakuan D (padat tebar 5 ekor/l air) dengan rata rata pertambahan panjang $7,71 \mathrm{~cm}$. Berdasarkan analisis sidik ragam, pemeliharaan benih ikan patin siam $(P$. 
hypopthalmus, F) dengan padat tebar yang berbeda pada pemeliharaan sistem akuaponik berpengaruh nyata terhadap pertambahan panjang benih ikan patin siam (P. hypopthalmus, F) $(\mathrm{P}<0,05)$. (Tabel 3).

Hasil pengamatan menunjukkan bahwa panjang total ikan tertinggi selama 30 hari bukan pada perlakuan A (padat tebar terendah yaitu 2 ekor/l air) melainkan ada pada perlakuan B dan C dengan kepadatan 3 dan 4 ekor/ 1 air yaitu rata-rata sebesar $7,91 \mathrm{~cm}$. Hal ini disebabkan karena pada masa pemeliharaan 20 sampai 30 hari, pada perlakuan B dan C mengalami peneurunan SR (banyak terjadi kematian) sehingga jumlah ikan pun berkurang sehingga memberikan ruang gerak yang luas dan mengurangi proses kompetisi makan ikan patin tersebut.

Dalam hal ini juga diperkuat dengan hasil pertambahan panjang benih ikan patin pada perlakuan A yaitu pada masa pemeliharaan 0 sampai dengan 20 hari dimana pertambahan panjang nya lebih baik dari pada perlakuan yang lain yaitu sebesar 7,21 cm. Hal ini sesuai dengan hasil penelitian Mangampa, dkk (2008), yang menyatakan bahwa semakin besar kepadatan ikan yang kita berikan, akan semakin kecil laju pertumbuhan per individu. Dengan kepadatan rendah ikan mempunyai kemampuan memanfaatkan makanan dengan baik dibandingkan dengan kepadatan yang cukup tinggi, karena makanan merupakan faktor luar yang mempunyai peranan di dalam pertumbuhan (Syahid $d k k, 2006$ ). Cholik et al, (1990) juga menambahkan padat penebaran akan mempengaruhi kompetisi ruang gerak, kebutuhan makan dan kondisi lingkungan yang nantinya akan mempengaruhi pertumbuhan dan sintasan yang akan terlihat pada hasil produksi akhir.

\section{Pertambahan Bobot Benih Ikan Patin Siam (P. hypopthalmus, F)}

Berdasarkan data pada tabel 3 terlihat bahwa padat tebar benih ikan patin yang berbeda pada pemeliharaan sistem akuaponik tidak memberikan pengaruh terhadap pertambahan bobot benih ikan patin siam ( $P$. hypopthalmus, F). Untuk melihat rata-rata jumlah pertambahan bobot benih ikan patin siam ( $P$. hypopthalmus, F) selama penelitian pada setiap perlakuan dapat dilihat pada gambar grafik di bawah ini.

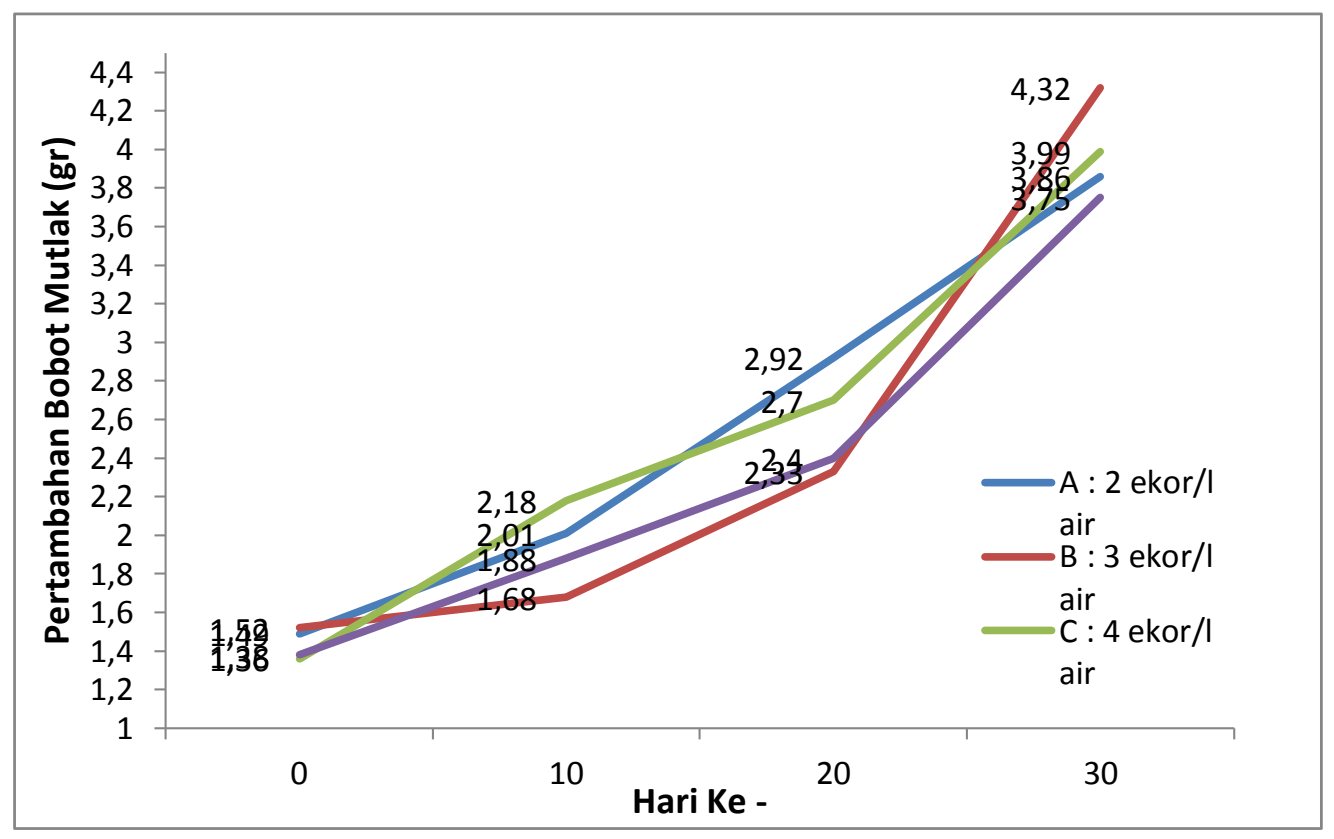

Gambar 3. Grafik pertambahan bobot benih ikan patin siam

Pada gambar 3 grafik di atas menjelaskan bahwa hasil pertambahan bobot benih ikan patin siam $(P$. hypopthalmus, F) dengan padat tebar yang berbeda menghasilkan nilai pertambahan bobot tubuh ikan patin tertinggi ada pada perlakuan B (3 ekor/l air) sebesar 4,32 gr, kemudian diikuti oleh perlakuan C (4 ekor/l air) sebesar 3,99 gr. Selanjutnya ada perlakuan A (2 ekor/l air) sebesar 3,86 gr, dan yang terakhir adalah perlakuan D (5 ekor/l air). Perlakuan tidak berpengaruh nyata terhadap pertambahan bobot benih ikan patin siam $(P$. hypopthalmus, $\mathrm{F})$ $(\mathrm{P}>0,05)$. (Tabel 3).

Dengan demikian, adanya peningkatan padat tebar tinggi hingga perlakuan 5 ekor/l telah menurunkan laju pertumbuhan bobot dan laju pertumbuhan panjang benih ikan patin siam ( $P$. hypopthalmus, F). Hal ini terjadi karena perlakuan pada padat tebar tertinggi telah melampaui daya dukung perairan. Menurut Solehudin (2006) daya dukung carrying capacity merupakan kemampuan suatu perairan untuk dapat mendukung kehidupan biota dalam perairan tersebut tanpa menambah atau mengurangi biomassanya. 


\section{Kualitas Air}

Parameter kualitas air yang perlu dikelola dalam budidaya ikan antara lain suhu, $\mathrm{pH}$, oksigen terlarut, derajat keasaman dan ammonia (Boyd, 1982). Parameter kualitas air yang diamati selama penelitian diantaranya suhu, $\mathrm{pH}$, $\mathrm{DO}, \mathrm{CO}_{2}$, Ammonia, nitrat dan nitrit. Untuk pengamatan suhu, $\mathrm{DO}, \mathrm{Ph}$, dilakukan dilokasi penelitian yaitu instalasi perikanan taman anggrek. Sementara untuk pengujian ammonia, $\mathrm{CO}_{2}$, nitrat dan nitrit dilakukan di laboratorium dasar Universitas Batanghari Jambi. Hasil dari pengukuran parameter kualitas air selama penelitian dapat dilihat pada pada Tabel 4 di bawah ini.

Tabel 2. Hasil Pengukuran parameter kualitas air setiap perlakuan selama penelitian.

\begin{tabular}{|c|c|c|c|c|c|c|}
\hline \multirow{3}{*}{ No } & \multirow{3}{*}{$\begin{array}{l}\text { Parameter } \\
\text { Kualitas Air }\end{array}$} & \multicolumn{4}{|c|}{ Akuarium Perlakuan } & \multirow{3}{*}{ Baku Mutu } \\
\hline & & \multicolumn{4}{|c|}{ Nilai/Kisaran } & \\
\hline & & $\mathbf{A}$ & B & $\mathbf{C}$ & D & \\
\hline 1 & Suhu $\left({ }^{\circ} \mathrm{C}\right)$ & $28,7-31$ & $28,7-31,1$ & $28,7-31,1$ & $28,7-31,5$ & $25-32^{\circ} \mathrm{C}$ (Boyd, 1982) \\
\hline 2 & pH & $5-7$ & $5-7$ & $5-7$ & $5-7$ & 7-8,5 (Barus, 2001) \\
\hline 3 & DO (mg/l) & $4-7$ & $4-7$ & $4-7$ & $3-7$ & > 3 mg/l (Zonneveld, et al 1991) \\
\hline 4 & $\mathrm{CO}_{2}(\mathrm{mg} / \mathrm{l})$ & 0,345 & 0,451 & 0,577 & 0,803 & < 10 mg/l (Zonneveld, et al 1991) \\
\hline 5 & Ammonia (mg/l) & 0,0111 & 0,0133 & 0,0125 & 0,0129 & $<0,2 \mathrm{mg} / \mathrm{l}($ Effendie, 2003$)$ \\
\hline 6 & Nitrat (mg/l) & 0,26 & 0,12 & 0,35 & 0,25 & 0,1-2 (Lab. Dasar Univ. Batanghari, 2017) \\
\hline 7 & Nitrit (mg/l) & 0,028 & 0,018 & 0,022 & 0,005 & $<1$ (Siikavuopio \& Saether. 2006) \\
\hline
\end{tabular}

Pada tabel 2 tertera data kualitas air selama penelitian pada setiap perlakuan. Secara umum parameter kualitas air tersebut masih memenuhi standar baku mutu bagi kehidupan ikan pati siam ( $P$. hypopthalmus, $\mathrm{F})$, hanya saja nilai pH pada setiap perlakuan dari waktu ke waktu mengalami penurunan hingga mencapai angka 5 yang artinya air bersifat asam.

Suhu media pemeliharaan ikan patin siam ( $P$. hypopthalmus, F) selama penelitian berkisar antara $28,7^{0} \mathrm{C}-$ $31,5^{\circ} \mathrm{C}$ (Tabel 2) sehingga masih dalam kisaran normal (Boyd, 1982). Suhu merupakan salah satu faktor fisika perairan yang sangat penting dan berpengaruh bagi pertumbuhan ikan. Ikan merupakan hewan poikilothermal yaitu hewan yang memiliki suhu tubuh yang sama dengan suhu lingkungan sekitarnya. Ikan merupakan hewan berdarah dingin sehingga suhu berpengaruh langsung pada laju metabolisme ikan. Perubahan suhu dapat menyebabkan perubahan laju metabolisme ikan, semakin tinggi suhu media maka laju metabolisme ikan juga akan meningkat sehingga nafsu makan ikan meningkat.

Selama penelitian berlangsung, suhu air media pemeliharaan relatif stabil dengan adanya penggunaan sistem biofiltrasi dengan akuaponik. Hal ini diperjelas oleh pernyataan Samsundari dan Ganjar (2013) yang menyatakan bahwa suhu air relatif konstan dengan adanya proses filtrasi pada biofiltering, hal ini dikarenakan adaanya peran sistem resirkulasi dan biofilter dalam menjaga suhu air yang semula rendah setelah melalui sistem resirkulasi yaitu air digerakan oleh pompa air dan memasuki proses biofiltrasi maka terjadi gesekan mekanis antara partikel air, media tanam dan akar tanaman sehingga suhu air dalam kolam dapat meningkat dan cenderung lebih konstan.

Derajat keasaman $(\mathrm{pH})$ adalah suatu konsentrasi ion hidrogen dan menunjukan air tersebut bersifat asam atau basa. Keasaman $(\mathrm{pH})$ yang suboptimal berakibat buruk pada spesies kultur dan menyebabkan ikan stres, mudah terserang penyakit, produktivitas dan pertumbuhan rendah. Kisaran $\mathrm{pH}$ air media pemeliharaan ikan patin siam selama penelitian berkisar anatar 5 - 7. Dalam hal ini (Putra, 2013) menjelaskan bahwa, untuk ikan jenis catfish mampu mentolerir dan hidup dalam perairan atau lingkungan yang bersifat asam hingga $\mathrm{pH} 5$ sekalipun dan bisa bertahan pada perairan basa hingga $\mathrm{pH}$ 9. Nilai $\mathrm{pH}$ mempunyai pengaruh besar terhadap kehidupan organisme perairan, sehingga $\mathrm{pH}$ perairan dipakai sebagai salah satu komponen untuk menyatakan baik buruknya sesuatu perairan.

Oksigen terlarut adalah oksigen dalam bentuk terlarut didalam air karena ikan tidak dapat mengambil oksigen dalam perairan secara difusi langsung dari udara (Gusrina, 2008). Tingkat konsumsi oksigen ikan bervariasi tergantung pada suhu, konsentrasi oksigen terlarut, ukuran ikan, tingkat aktivitas, waktu setelah pemberian pakan dan lain sebagainya. Tingkat metabolisme juga bervariasi antar spesies dan dibatasi oleh rendahnya kandungan oksigen yang tersedia. Pada umumnya, ikan kecil akan mengkonsumsi oksigen per berat badan lebih banyak dibandingkan ikan besar dari satu spesies. Oksigen terlarut dibutuhkan oleh semua jasad untuk pernafasan, proses metabolisme atau pertukaran zat yang kemudian menghasilkan energi untuk pertumbuhan dan perkembangbiakan juga untuk oksidasi bahan-bahan organik dan anorganik dalam proses aerobik. Nilai kandungan oksigen terlarut (DO) pada media pemeliharaan ikan patin siam (P. hypopthalmus, F) dari awal hingga akhir penelitian berkisar antara $3-7 \mathrm{mg} / \mathrm{L}$. Kisaran ini masih berada dalam kisaran yang mendukung untuk kehidupan ikan. Hal ini menunjukkan adanya pengaruh sintesa tumbuhan pada sistem resirkulasi terhadap kandungan oksigen terlarut dalam 
air. Kandungan oksigen terlarut yang ideal di dalam air untuk budidaya ikan tidak boleh $<3,00 \mathrm{mg} / \mathrm{l} \mathrm{karena}$ dapat menyebabkan kematian organisme air (SNI 7550, 2009).

Nilai korbondioksida bebas selama penelitian berkisar antara antara $0.098-0,803 \mathrm{mg} / \mathrm{l}$ nilai ini masih dalam kondisi yang normal untuk pertumbuhan ikan patin siam (P. hypopthalmus, F). Menurut Effendie (2003), karbondioksida merupakan hasil buangan akibat adanya proses pernafasan mahkluk hidup. Pada konsentrasi tinggi (> $10 \mathrm{mg} / \mathrm{l}$ ), karbondioksida dapat beracun karena keberadaannya di dalam darah dapat menekan aktivitas pernapasan ikan dan menghambat pengikatan oksigen oleh hemoglobin sehingga dapat membuat ikan menjadi stress. Kandungan karbondioksida didalam air untuk pembesaran ikan sebaiknya kurang dari $10 \mathrm{mg} / \mathrm{liter}$ (Zonneveld, et al (1991).

Menurut Zonneveld (1991), ammonia merupakan hasil akhir dari proses metabolisme protein. Konsentrasi ammonia selama penelitian berkisar antara $0,0111-0,0133 \mathrm{mg} / \mathrm{l}$, pada semua perlakuan kisaran nilai ammonia masih berada dalam konsentrasi yang bisa ditolerir oleh ikan. hal ini terjadi karena adanya bakteri yang dapat memecah limbah dari ikan, yaitu bakteri Nitrosomonas, yang mengubah Ammonia menjadi Nitrit, Nitrit ini kemudian diubah menjadi Nitrat oleh bakteri Nitrobacter, sehingga tanaman kemudian dapat mengkonsumsi nitrat untuk tumbuh, dengan demikian ammonia yang dihasilkan ikan akan habis dengan adanya proses nitrifikasi dan penyerapan nitrat oleh tanaman (Samsundari dan Ganjar 2013). Putra (2015) menambahkan, bakteri yang bekerja pada proses nitrifikasi dapat mengubah amonia $\left(\mathrm{NH}_{3}\right)$ yang berasal dari kotoran ikan menjadi Nitrit $\left(\mathrm{NO}_{2}{ }^{-}\right)$kemudian diubah lagi menjadi Nitrat $\left(\mathrm{NO}_{3}^{-}\right)$melalui proses nitrifikasi dan terakhir diubah menjadi Nitrogen $\left(\mathrm{N}_{2}\right)$ bebas yang tidak berbahaya oleh ikan. Kadar ammonia yang tinggi dapat menyebabkan naikkanya kadar $\mathrm{pH}$ darah dan memiliki efek yang merugikan pada reaksi berbagai enzim dan stabilitas membran. Efek negatif tersebut meliputi kerusakan insang, pengurangan kapasitas darah dalam membawa oksigen serta kerusakan histologi pada sel darah merah (Boyd, 1998).

Nitrit (NO2) biasanya ditemukan dalam jumlah yang sangat sedikit di perairan alami, kadarnya lebih kecil dari pada nitrat karena nitrit bersifat tidak stabil jika terdapat oksigen (Effendi, 2003). Hal ini terlihat dari hasil pengukuran kadar nitrit pada akhir penelitian yaitu kandungan nitrit tertinggi terdapat pada perlakuan A (2 ekor/l air) sebesar $0,028 \mathrm{mg} / \mathrm{l}$ sedangkan kadar nitrit terendah ada pada perlakuan D (5 ekor/l air) sebesar 0,005 mg/l. Pada akhir penelitian justru perlakuan A (padat tebar terendah) yang memiliki kadar nitrit tertinggi dan perlakuan D (padat terbar tertinggi) dengan kadar nitrit terendah, hal ini dikarenakan pada akhir penelitian tingkat kelangsungan hidup pada perlakuan A adalah yang tertinggi dari semua perlakuan sedangkan pada perlakuan D tingkat kelangsungan hidupnya terendaha dari semua perlakuan. Namun terlepas dari itu semua kandungan nitrit ini masih dalam batas normal. Karena Kadar optimun nitrit perairan adalah antara $0,01-1,0 \mathrm{mg} / \mathrm{l}$ (Hendrawati, 2007). Senyawa nitrit yang berlebih dalam suatu perairan akan menyebabkan menurunnya kemampuan darah organisme perairan untuk mengikat $\mathrm{O}_{2}$, karena nitrit akan beraksi lebih kuat dengan hemoglobin yang menyebabkan tingginya tingkat kematian.

\section{KESIMPULAN DAN SARAN}

Padat tebar yang berbeda dengan sistem akuaponik pada pemeliharaan ikan patin siam (P. hypopthalmus, F) menghasilkan tingkat kelangsungan hidup yang berbeda nyata dimana perlakuan A merupakan perlakuan yang terbaik dengan tingkat kelangsungan hidup tertinggi sebesar $85,18 \%$, sedangkam untuk pertumbuhan terbaik ada pada perlakuan B dan C. Dalam hal ini dapat disimpulkan bahwa pada sistem akuaponik, faktor padat tebar tidak terlalu berpengaruh terhadap tingkat kelangsungan hidup benih ikan patin siam ( $P$. hypopthalmus, F), fungsi sistem akuaponik hanya mampu menunjang kegiatan pemeliharaan sebagaimana standar kepadatan tebar sistem budidaya normal.

Saran yang dapat diberikan dalam penelitian ini adalah pemeliharaan ikan patin siam (P. hypopthalmus, F) dengan menggunakan sistem akuaponik untuk tujuan produksi sangat baik digunakan namun dengan tingakat kepadatan benih sesuai dengan standar yang normal. Selain itu sistem akuponik sebaiknya diterapkan dalam kegiatan budidaya ikan patin karena dengan sistem akuaponik kita dapat menghemat penggunaan air sebagai media pemeliharaan sebab penggunaan sistem akuponik dapat memperbaiki kualitas air pemeliharaan sehingga dapat digunakan secara berulang-ulang.

\section{DAFTAR PUSTAKA}

Barus,T.A. 2002. Pengantar Limnologi. Universitas Sumatera Utara. Medan.

Breet, J.R. 1979. Environmental factors and growth. In: W.S. Hoar; O.J. Randal and J.R. Breet (Edotors). Fish Physiology, Vol, VIII. New York: Academic Press, hal. 599-675.

Boyd. 1990. Water Quality in Ponds for Aquaculture, Birmingham Publishing Co., Birmingham, Alabama, USA. 
Chou, L.M. 1994. Growth of Hybrid Catfhishes Under Different Supplemental Diets. The Third Asian Fishes Forum. Asian Fisheries Society, Manila, Philippines. pp. 633-636.

[DJPB] Direktorat Jenderal Perikanan Budidaya. 2011. Usaha budidaya lele dan gurami saat ini. http://www.perikanan-budidaya.kkp.go.id [15 Mei 2011].

Donk, H. 2015. Enam Model Akuaponik Untuk Lahan Sempit . Fokus Tanaman . //Blogspot.com

Effendi. H. 2000. Telaah Kualitas Air. Jurusan Manajemen Sumber Daya Peraiaran. Fakultas Perikanan Dan Ilmu Kelautan. IPB.

Forteath, N., Wee, L. and Frith, M., (1993), Water Quality, in P. Hart and O'Sullivan (eds) Recirculation System : Design, Construction and Management, University of Tasmania at Launceston, Australia.

Madinawati. N.S dan Yoel. 2011. Pemberian pakan yang berbeda terhadap pertumbuhan dan kelangsungan hidup benih ikan lele dumbo (Clarias gariepinus). Media Litbang Sulteng.

Rukmana, H.R. 2003. Budidaya dan Pascapanen Lele Dumbo. CV. Aneka Ilmu Anggota IKAPI. Semarang.

Saanin, H. 1968. Taksonomi dan Kunci Identifikasi Ikan Jilid I dan II. Bandung: Bina Cipta.

Subandiyono, Nisrinah Dan Elfitasari. 2013. Pengaruh Penggunaan Bromelin Terhadap Tingkat Pemanfaatan Protein Pakan Dan Pertumbuhan Lele Dumbo (Clarias Gariepinus).

Urbanina. 2016. Sistem Akuaponik Kelebihan Dan Kekurangan . //blogspot.com

Yamagata Y, Niwa M. 1982. Acute and choronic toxicity of ammonia to ell Anguilla japonica. Bull.Jap. Soc. Sci.Fish. 48 (2), 171-176

Zonneveld. N, E. A. Huisman, J. H. Boon. (1991). Prinsip-prinsip budidaya ikan. Gramedia Pustaka Umum. Jakarta 